\title{
A Human Rights-Based Approach to Education: Role of Local Government
}

\author{
Lucia Ch. O. Tahamata* Muhammad Ashri Marwati Riza Aminuddin Salle \\ Faculty of Law, Hasanuddin University, Makassar, Indonesia
}

\begin{abstract}
Educating the life of the nation is the main key for the Indonesian people to prepare, advance the mastery of science and technology as a constitutional right. Hence, the responsibility for fulfilling education to citizens is inherent in the family, society and government. The existence of the government is not held to serve self-interest, but to serve the interests and needs of the community. This research is a normative legal research with sociolegal approach. The researcher examines the principles related to fulfilling the basic rights in the field of education. The results show that the right to obtain education is seen as an international legal agreement. The obligation of the state to meet the educational needs of students, both the obligations of the results and the obligations of action have not been fulfilled optimally. Implementation of government responsibility for fulfilling the right to education with dimensions of availability, acceptability aspects, acceptable aspects, adaptation aspects, can be achieved if educational standards are met. Nowadays, the fact is that these four aspects are still very low in achievement. Therefore, three state functions in the issue of human rights, namely to Protect; to fulfill; and to promote have not been implemented optimally. As a result, citizen ownership of the four pillars of education, such as learning to know, learning by doing, learning to be, as well as learning to live together, in practical level, need to be a major concern of the stakeholders.
\end{abstract}

Keywords: Education; Human Rights; Local Government

DOI: $10.7176 / \mathrm{JLPG} / 85-22$

Publication date:May $31^{\text {st }} 2019$

\section{Introduction}

The goal of a human rights-based approach to education is simple: to assure every child a quality education that respects and promotes her or his right to dignity and optimum development. ${ }^{1}$ Achieving this goal is, however, enormously more complex. Hence, human rights are protected internationally, which means they apply to all humans without discriminating according to race, belief, social status, class, ethnicity and nation. ${ }^{2}$

In practice, human rights violations often occur in vulnerable groups. Vulnerable groups are those who belong to a group of people who are entitled to treatment and protection more favorably with their specificity. According to the Human Right Reference, stated that those belonging to the vulnerable group, such as refugees, Internally Displaced Persons (IDPs), national minorities, migrant workers, indigenous peoples, women and children. ${ }^{3}$

Children as vulnerable groups have special rights due to their limitations. This makes children need protection for their rights. Child protection is all activities to guarantee and protect children and their rights so that they can live, grow, and participate optimally in accordance with the dignity and the right to education, so that they get protection from violence and discrimination.

The current development is "privatization of education" which causes education to be expensive, and not affordable to the wider community, especially groups of children living in remote and poor areas. This happened partly because of the legalization of the commercialization of education with its various modus operandi. The state as a maker and controller of policy is not enough to provide protection against the expansion of global capitalism into the world of education. So that legislation products that should be protective for equal distribution of education for citizens have not been effectively formulated. ${ }^{4}$

Indonesia together with other countries in the world have accepted and signed the Education for All Declaration produced by the world conference held by UNESCO. Obligatory in this case means that there are no obstacles for school-age children to enjoy basic education, and the elimination of forms and practices of discrimination occur in terms of equal access between girls and boys in obtaining basic education. ${ }^{5}$ Meanwhile, it it can only be interpreted that the availability of state-run basic education is carried out without charging fees from children, parents or other parties.

Above all, efforts to educate the life of the Indonesian nation can only be done through the provision of

Tibbitts, F. (2002). Understanding what we do: Emerging models for human rights education. International review of education, 48 (3-4), 159-171.

Boer Mauna. (2006). Hukum Internasional: Pengertian Peranan dan Fungsi dalam Era Dinamika Global. Bandung: PT. Alumni, p. 675 Willem Van Genugten, J.M. (1994). Human Rights Reference, the Hague: Netherlands Ministry of foreign Affairs, p 73

Priyono Pujo, (2004). Lagalisasi Kapitalisme Pendidikan, Majalah Pendidikan, Yogyakarta, 2,(4).

Compare to Manfred Nowak, (2003). Introduction to the internstional Human Rights Regime (Translated by: Sri Sulatini, Jakarta: Raoul Wallenberg Institute and Dephuk \& HAM, p. 87 
education to Indonesian citizens. Educating the life of the nation is the main key for the Indonesian people to prepare, advance the mastery of science and technology for the realization of the welfare of all the people of Indonesia and can play its role in international relations that benefit humanity. ${ }^{1}$ To educate the life of the nation, education becomes a means or container. It can be said that education is 'conditio sinequa non' to educate the life of the Indonesian people. Without obtaining education, it is impossible for the goal of educating the life of the Indonesian nation to be realized. Therefore, the government must pay attention and fulfill education to Indonesian citizens as a basic need as well as other basic needs as an effort to educate the life of the Indonesian nation.

Philosophically, the responsibility for fulfilling education to citizens is inherent in the family, society and government. The existence of the government is not held to serve self-interest, but to serve the interests and needs of the community. ${ }^{2}$ Therefore, one of the government's responsibilities to serve the interests and needs of the community is to fulfill education to citizens. However, this is a fundamental principle in the life of the state that changes the view that the government is only a ruler who only rules. The responsibility for realizing public welfare is borne by the government and is not the responsibility of citizens. ${ }^{3}$ Observing this phenomenon, the issue of research is the lack of fulfillment of basic rights in the field of education based on human rights.

\section{Method of the Research}

This research is a normative legal research with sociolegal approach. The researcher examines the principles related to fulfilling the basic rights in the field of education for the island community, the responsibility of the local government for fulfilling the basic rights in the field of education, and the concept of ideals in fulfilling basic rights in the field of education. Data collected both primary and secondary are analyzed using qualitative analysis.

\section{Legal Responsibilities of Local Government to the Education as Constitutional Rights}

The quality of learning outcomes and the efficiency of national education have yet to show an encouraging level of achievement. The low quality of learning outcomes, the high rate of drop out in elementary schools, the gap between schools and the world of work, and a centralized curriculum are examples of national education that has not received serious attention. Coupled with the teaching model that has been conservative and verbalistic in which children are only fed with a set of information from the brain to the brain (transfer of head) without building character that is based on religious, cultural and moral values (transefer of values).

The international community and leading development institutions have agreed to the Millennium Development Goals, expressed in the Millennium Declaration, which commit them to ensuring that all girls and boys complete a full course of primary education and that gender disparity is eliminated at all levels of education by 2015. More recently, the 'International Conference on the Right to Basic Education as a Fundamental Human Right and the Legal Framework for Its Financing' (Jakarta, Indonesia, 2-4 December 2005) adopted the Jakarta Declaration. ${ }^{4}$ This emphasizes that the right to education is an internationally recognized right in its interrelationship with the right to development, and that the legal and constitutional protection of this right is indispensable to its full realization. ${ }^{5}$

Indeed, children's education in the Millennium Development Goals is a declare of all children 's rights to education, so that it becomes the responsibility of the state through the government to fulfill it. According to Lempert, ${ }^{6}$ in the case of rights education, because "right" and "education" have been defined as something "good" their proponents say that supporting them with infinite funds will lead to an infinite, though immeasurable, good while oposing them is somehow immoral or uninformed. Far too often, projects measure benefit to interested parties who spend public and private money on these projects (the stakeholder implementing agents rather than to the public beneficiaries or the taxpaying public. Additionally, such measurement is done withoud clear and measurable impact criteria that ascertain the degree to which such projects fulfii the mission in this field set by international law.

However, as it turns out to the practice, the government's formal commitment to the issue of human rights enforcement can be measured, one of which is the number of international human rights instruments ratified. Because each instrument defines the responsibility of the government. But in reality, the formal commitment is not enough to assess the government's commitment. Thus, what happened so far, the government ratified human rights instruments, but it was not necessarily fully implemented.

Johan Jasin, (2010), Tanggung Jawab Pemerintah Daerah Terhadap Perlindungan Hukum Hak Anak Dalam Memperoleh Pendidikan, Program Pasca Sarjana Universitas Hasanuddin, Makassar, p. 3.

Aminuddin Ilmar, (2013), Hukum Tata Pemerintahan, Identitas Universitas Hasanuddin, Makassar, p. 16.

Jemmy Jefry Pietersz, (2016), Pengujian Dalam Pengunaan Kewenangan Pemerintahan, (Dissertation), Program Doktor Fakultas Hukum Universitas Airlangga, Surabaya, p. 6.

4 Craissati, D., Banerjee, U. D., King, L., Lansdown, G., \& Smith, A. (2007). A human rights based approach to education for all. United Nations Children's Fund/United Nations Educational, Scientific and Cultural Organization, p. 9.

Ashri, M. (2018). Hak Asasi Manusia: Filosofi, Teori dan Instrumen Dasar. Makassar: Social Politic Genius.

6 David Lempert. (2008). A human Right Education Project Indicator for NGOs and International Organizations, p, 51 
State responsibility is an important issue that is always discussed in international law. For this reason, the International Law Commission (ILC) tried to study and codify the state's responsibility. Judging from the aspect of international law, there are two kinds of state accountability theories, namely: First, Risk Theory, which then gives birth to the principle of absolute liability or objective responsibility that a country is absolutely responsible for every activity which results in harmful effects of ultrahazardous activities even though the activity itself is a lawful activity.

Secondly, fault theory, which gives birth to the principle of subjective responsibility or liability based on fault, namely that the state's responsibility for its actions is only said to exist if it can be proven that there is an element of error in the act. In international law, state responsibility is defined as an obligation that must be carried out by the state to other countries based on international law orders. ${ }^{1}$ For instance, if a country does not fulfill the obligations imposed on it based on international law, it can be asked for responsibility. To be able to judge, what needs to be considered is about the actions of a country in public capacity (iure empire) and prifat (iure gestiones). The concept of actual state responsibility is born as an effort to distinguish state actions that are public or civil sector. $^{2}$

From the state level down to the individual parent lie differing levels of obligation for fulfilling the right to education, but it is essential that clear and appropriate lines of accountability are drawn. For example, parents cannot fulfil their obligations to ensure that their child is prepared for and attends school on a regular basis unless the government has provided the schools and the economic environment to support that attendance. Recognition also needs to be given to the fact that every adult has rights as well as responsibilities ${ }^{3}$. In addition, a wrong state action that can cause responsibility is when an action or omission is attached to the state based on the country's international law. ${ }^{4}$ The attribution element is an important part of assessing whether wrong state actions are carried out in public or civil capacity. Moreover, one of the objectives of the draft state convention is to highlight state actions in the public sphere.

Interesting phenomena in the world of education to be studied in depth are associated with the concept of human rights and are associated with the function of the state as a facilitator of public interest, which is responsible and at the same time administering education. The following actions are necessary on the part of States if they are to fulfil the Education for All goals and ensure the right to a quality education for all children that is respectful of their rights. These actions can also serve as benchmarks or indicators for monitoring the implementation of human rights-based education:

\section{a. Availability}

Availability requires the government to build schools and provide the resources needed to develop educational institutions. The Constitution regulates the importance of the education of Article $28 \mathrm{C}$ paragraph (1) of the 1945 Constitution $^{5}$ and Article 31 of the 1945 Constitution that education is the right of every citizen. Therefore, the government is obliged to guarantee the availability of educational services as the responsibility of the state. The right to education must include the right to adequate school capacity and school space. The state failed to guarantee the education available when it failed to provide adequate educational institutions with the distribution evenly distributed to all jurisdictions of the unitary Republic of Indonesia by not distinguishing between cities and villages, between large and small islands. This includes allowances for educators working in disadvantaged and remote areas.

\section{b. Accessibility}

Accessibility refers to the ability of all individuals physically and economically to access and obtain education without discrimination based on $\mathrm{ECESCR}^{6}$ that all education must be economically accessible, but the ICESCR goes further with respect to primary education. It requires that state parties either immediately provide free primary education to all at the time of ratification or adopt a plan within two years to provide full realization of free primary education within a reasonable number of years.

The availability of educational facilities and infrastructure is the main requirement so that access to education is prepared by the state through the government. Physical education must be safe to reach. Economically education must be affordable and basic education must be free and free of charge.

Robecca M.M Wallace, (2002), International Law, Fourth Edition, Sweet \& Maxwell, London, p.174

Chia lehnardt, (2007). Private military companies and state responsibility, international Law and Justice Papers, NYU Law School, p. 5 Ariani Arifin. (2011). "Tinjauan Yuridis Pelaksanaan Pemutusan Hubungan Kerja Terhadap Pekerja Outsourcing”, Amanna Gappa, 19 (1): 51-71

Draft Articles on the reponsibility of states for international wrongful Acts, Art. 2

Article 28 C para. (1) of the 1945 Constitution stated that "Everyone shall be entitled to develop themselves through the fulfilment of their basic necessities, receive education and benefit the science and technology, art and culture, to improve the quality of their life and for the welfare of the mankind".

6 Tomasevski, clarifes these obligations by stated that governments are thus obliged to ensure with immediate effect that primary education is compulsory and available free of charge to formulate a plan and seek international assistance to fulfill this obligation as speedily as possible" Tomassevski 2004 Repot, supra note 35, at para 23

7 Riyadi, E. (2017). Hukum Hak Asasi Manusia. Jakarta: PT Raja Grafindo Persada, p.113 


\section{c. Afordable}

High-quality education for all educational institutions is a necessity as an absolute requirement to ensure the achievement of goals, therefore education supervision is necessary in order to control quality. In addition, there are legal regulations that set standards for quality education.

\section{d. Adaptability}

ICESCR signatory countries must ensure that education is adaptable, ${ }^{1}$ that is the education system must be able to accommodate students who may need special arrangements because of their individual needs or specific social or cultural backgrounds in order to maintain them in the system. The constitution provides guarantees for basic rights, minority rights for education that respect and develop their cultural identity and special education for children with disabilities or disabilities.

Quality, civilized, and able to humanize education can be achieved if we pay attention to the principles of long life education and four pillars (joints) of education. The four pillars of education in question are: (1) learning to know (learning to know, (2) learning to do (degree by doing, (3) learning to be (learning to be someone) and (4) learning to live together with to live others (learning to live together in its implementation. Because by actualizing the four pillars and principles of lifelong education, the education process will gain acquisition in the form of knowledge (cognition), psychic(motoric) skills, and the cultivation of human attitudes or affective character quality that is useful for his life.

\section{Education rights and state obligations: Towards an improved understanding of the education as a constitutional right}

Education is a constitutional right guaranteed by the 1945 Constitution as the highest law in Indonesia. Therefore, the state is obliged to realize these rights without discrimination from all aspects of the fulfillment of Indonesian citizenship rights based on the 1945 Constitution. The right to education, including various aspects of freedom of education and academic freedom, is an important part of human rights law.

The application of the principle of non-discrimination towards the fulfillment of the right to education needs to be applied as a whole from fundamental norms to government regulations. This shows that how legislators are aware of the importance of the principle of non-discrimination as one of the foundations for the realization of the equality of education for all Indonesian children. ${ }^{2}$

Table 1. Education rights and state obligations

\begin{tabular}{|c|c|c|}
\hline $\begin{array}{c}\text { State } \\
\text { Obligations }\end{array}$ & Dimension & Freedom \\
\hline \multirow[t]{4}{*}{ Appreciation } & Freedom of choice & Freedom to establish \\
\hline & Prevent forms of indoctrination or coercion & Respect for freedom \\
\hline & Appreciate the freedom to choose in school & $\begin{array}{l}\text { Establish schools with minimum } \\
\text { standards in accordance with legal } \\
\text { provisions }\end{array}$ \\
\hline & Respect for human dignity & $\begin{array}{l}\text { Respect (cultural) differences } \\
\text { education }\end{array}$ \\
\hline \multirow[t]{4}{*}{ Protection } & $\begin{array}{l}\text { Prevent forms of indoctrination or coercion by } \\
\text { other parties }\end{array}$ & \multirow[t]{4}{*}{$\begin{array}{l}\text { Implement and uphold the principle of } \\
\text { equality }\end{array}$} \\
\hline & Protect legal freedom to choose & \\
\hline & $\begin{array}{l}\text { Eliminate discrimination in acceptance of } \\
\text { students in private school }\end{array}$ & \\
\hline & Ensure pluralism in the curriculum & \\
\hline \multirow[t]{2}{*}{ Fulfilling } & Support different forms of education & \multirow{2}{*}{$\begin{array}{l}\text { Providing scholarship } \text { and support } \\
\text { agencies }\end{array}$} \\
\hline & $\begin{array}{l}\text { Promote tolerance and mutual understanding of } \\
\text { educational programs among all community } \\
\text { groups }\end{array}$ & \\
\hline
\end{tabular}

Source: Primary data, 2018 (edited).

The state is obliged to carry out international obligations in the fulfillment of education rights to the maximum based on existing resources. The absence or lack of resources is not an excuse for not implementing it. The realization of the implementation of the commitment of obligation obliges the state to make a specific plan of action or program for the fulfillment of human rights based on the application of the principle of effectiveness in its territory and/or in its jurisdiction. Hence, Education will run well if the education authorities carry out and understand their status, roles and functions in the world of education.

See general comment 13 , at para 6

Adopted by A.P.M. Coomans. the internatinal Protection of the Right to education, on van Genugten (ed), Human Right reference Hanbook,

2 Rev,ed (Netherland Ministry of Foreign Affairs, Human Right, Good Governance and Democratisation Departmen, 1999 ) p. 72 
Answering education has a major role in carrying out the learning process, both in the formal and informal sectors. There are 3 main elements to running a good education: Parents, Educators, and the Government itself. In order for education to run well, the first and foremost answer for students in the family is parents (life long education). The concept of lifelong education confirms that education in the family must be done. Therefore, parents must be responsible for continuing education in the family so that efforts to educate children both emotionally, intellectually and spiritually can be guaranteed well.

Parents as responsible for education have a very dominant role in the education process. However, between parents and children have an emotional connection and intensive educational interactions that can create an educational atmosphere. So from that, parents must be an example for children, and there is a relationship that truly reflects the educator figure who has great responsibility for the family.

As the responsible person, parents have a special position in the eyes of children. Because parents have a great responsibility in preparing and realizing the future of their children, as the chief responsible for parents should not allow the growth of children to walk without guidance or be left to the teachers in the school. Then, the responsibility of parents in education is two things: First, instill social values; Secondly, foster physical, psychological and intellectual development.

Educators also have responsibility for the ongoing process of education and teaching. Therefore in essence these educators are parents at school. Educators have a central position and role in the learning process, especially in school, even the rhythm of educational interaction is deliberately designed in such a way, systematic and methodological in order to facilitate students and absorb the knowledge given. The responsibility of the educator is not only tied to his formal duties, but outside the work of his obligations, in fact he is still required to assume that responsibility. Hence, that's why the teachers get the title as "Unsung Heroes" (also known in Indonesia as "Pahlawan Tanpa Tanda Jasa").

Educators, with all their duties are responsible for the formation and intellectual development of students in addition to coaching other aspects. Intellectual development in question is the formation and formation of thinking scholars with all things that are useful, science, civilization, modernization and awareness of thinking and culture. Observing their duties and functions as educators, the responsibility of the teaching staff is indeed very heavy, especially in the form of their responsibility to form a man of faith and piety, intelligent and skilled and capable of independently manifesting human beings who are full of resources and quality.

Besides the intellectual development of the teaching staff, they must also be able to direct students to respond to various cultural developments and accelerations that occur around them. The main responsibility of educators is to guide students or students who are ultimately able to live in independence, not dependent on others. This needs to be emphasized, because technological development and social acceleration spur and influence individual development in society and have a major influence on the social norms and systems of society, behavior, family structure, community mobility and level of competence.

How do the efforts of educators grow the creativity of students, so that they become dynamic and productive, not too dependent on people or the government in the sense of wanting to become civil servants? It is a question that is also relatively difficult to answer, considering that our current educational orientation emphasizes the formation of intellectuality, not independence.

Political decentralization to the local level is an essential component of democratization, good governance and citizen engagement; it should involve an appropriate combination of representative and participatory democracy. Participation through inclusiveness and empowerment of citizens shall be an underlying principle in decision-making, implementation and follow-up at the local level. ${ }^{1}$ Local authorities should recognize the different constituencies within civil society and should strive to ensure that all are involved in the progressive development of their communities and neighborhoods.

Local authorities should have the right to establish and develop partnerships with all actors of civil society, particularly non-governmental organizations and community-based organizations, and with the private sector and other interested stakeholders. Earmarked allocations shall be restricted to cases where there is a need to stimulate the local implementation of national policies, in areas such as environmental protection, social development and education.

Local government is commonly defined as the lowest tier of public administration within a given State. The duty to fulfil means that local government must take positive action to facilitate the enjoyment of the rights and freedoms. For example, local authorities are obliged to fulfil the right to education by sustaining a good educational system.

\section{Conclusion}

Fulfillment of basic rights in the field of education is a human right within the scope of economic, social and

Titahelu, J., Irwansyah, I., Awaludin, H., \& Ashri, M. (2015). Strengthening Pela-Gandong Alliance Based on John Rawls' Theory of Justice. Hasanuddin Law Review, 1(3), 417-429. doi:http://dx.doi.org/10.20956/halrev.vli3.119 
cultural rights. In international community, the right to obtain education is seen as an international legal agreement. Hence, the obligation of the state to meet the educational needs of students, both the obligations of the results and the obligations of action have not been fulfilled optimally. Implementation of government responsibility for fulfilling the right to education with dimensions of availability, acceptability aspects, acceptable aspects, adaptation aspects, can be achieved if educational standards are met. Nowadays, in fact, these four aspects are still very low in achievement. Therefore, three state functions in the issue of human rights, namely to Protect; to fulfill; and to promote have not been implemented optimally. As a result, citizen ownership of the four pillars of education, such as learning to know, learning by doing, learning to be, as well as learning to live together, in practical level, need to be a major concern of the stakeholders.

\section{References}

A.P.M. Coomans. the internatinal Protection of the Right to education, on van Genugten (ed), Human Right reference Hanbook, 2 Rev,ed (Netherland Ministry of Foreign Affairs, Human Right, Good Governance and Democratisation Departmen, 1999) p. 72

Aminuddin Ilmar, (2013), Hukum Tata Pemerintahan, Identitas Universitas Hasanuddin, Makassar.

Ariani Arifin. (2011). “Tinjauan Yuridis Pelaksanaan Pemutusan Hubungan Kerja Terhadap Pekerja Outsourcing”, Amanna Gappa, 19 (1): 51-71

Ashri, M. (2018). Hak Asasi Manusia: Filosofi, Teori dan Instrumen Dasar. Makassar: Social Politic Genius.

Boer Mauna. (2006). Hukum Internasional: Pengertian Peranan dan Fungsi dalam Era Dinamika Global. Bandung: PT. Alumni.

Chia lehnardt, (2007). Private military companies and state responsibility, international Law and Justice Papers, NYU Law School.

Craissati, D., Banerjee, U. D., King, L., Lansdown, G., \& Smith, A. (2007). A human rights based approach to education for all. United Nations Children's Fund/United Nations Educational, Scientific and Cultural Organization.

David Lempert. (2008). A human Right Education Project Indicator for NGOs and International Organizations.

Jemmy Jefry Pietersz, (2016), Pengujian Dalam Pengunaan Kewenangan Pemerintahan, (Dissertation), Program Doktor Fakultas Hukum Universitas Airlangga, Surabaya.

Johan Jasin, (2010), Tanggung Jawab Pemerintah Daerah Terhadap Perlindungan Hukum Hak Anak Dalam Memperoleh Pendidikan, (Dissertation) Program Pascasarjana Universitas Hasanuddin, Makassar.

Manfred Nowak, (2003). Introduction to the internstional Human Rights Regime (Translated by: Sri Sulatini, Jakarta: Raoul Wallenberg Institute and Dephuk \& HAM.

Priyono Pujo, (2004). Lagalisasi Kapitalisme Pendidikan, Majalah Pendidikan, Yogyakarta, 2,(4).

Riyadi, E. (2017). Hukum Hak Asasi Manusia. Jakarta: PT Raja Grafindo Persada.

Robecca M.M Wallace, (2002), International Law, Fourth Edition, Sweet \& Maxwell, London.

Tibbitts, F. (2002). Understanding what we do: Emerging models for human rights education. International review of education, 48 (3-4), 159-171.

Titahelu, J., Irwansyah, I., Awaludin, H., \& Ashri, M. (2015). Strengthening Pela-Gandong Alliance Based on John Rawls' Theory of Justice. Hasanuddin Law Review, 1(3), 417-429. doi:http://dx.doi.org/10.20956/halrev.v1i3.119

Willem Van Genugten, J.M. (1994). Human Rights Reference, the Hague: Netherlands Ministry of foreign Affairs. 